\title{
Village Spatial Planning Based on Its Potential as Guidelines for Guided and Sustainable Village Development
}

\author{
Mustika K. Wardhani ${ }^{1}$, Bambang Setioko ${ }^{2}$ and Edward E Pandelaki ${ }^{3}$
}

Received: $7^{\text {th }}$ October 2020

Accepted: $11^{\text {th }}$ November 2020

\begin{abstract}
Historical areas that support tourism activities will always adapt to match the complexity of tourism needs in the last few decades. The uniqueness of Kotagede is that there are traditional settlements of silver craftsmen's (Javanese: Abdi Dalem Kriya). The history of silver craftsmen's settlement has been formed since the Dutch colonial era and has survived until now as a characteristic of Kotagede. Silver craftsmen in Kotagede have a dilemma to survive for SMEs home-based or adapt to sell products to a larger-scale industry. The research objectives are to determine whether or not there is a change in the settlement area caused by the silver home-based industry activities and to what extent the change has occurred. The method used is a quantitative method with a positivistic paradigm and uses descriptive analysis for data interpretation. Statistical data analysis used multivariate linear regression (SPSS V26). In this study, it was found that there was an effect of Silver home-based industry activities on change in settlement area with the low significance of $25.6 \%$ while $74.4 \%$ was thought to be influenced by other activities outside the research model. Partially, the highest variable effect on settlement changes in production activities (X1) that can be found in Purbayan and Prenggan Village. With the low significant impact results on settlement changes, It is hoped that the silver home-based industry activities have the potential to be promoted as part of the survivability concept of tourism in Kotagede by advancing SMEs itself.
\end{abstract}

Keywords: silver craft home-based industry, changes in the settlement area, heritage tourism, survivability

\section{INTRODUCTION}

The structural transformation process in Indonesia is taking place rapidly. Many changes have occurred in all developing countries and regions in Indonesia are starting to develop the industrial sector, thereby reducing its gap with the agricultural sector. The business journey that the small industry has been through so far cannot be separated from the results of government policies and programs (Arifini \& Mustika, 2013). In this research, the Author will present how the impact of home-based industries on changes in the function of traditional and heritage settlement in Yogyakarta. Approximately $95 \%$ of the growing craft industry sector consists of the folk's handicraft industry and is directed to support Yogyakarta's program as the second city of a cultural centre and tourist destination after Bali (Daliman, 2012). The revival of arts and culture will stimulate new business opportunities in the market for arts and cultural tourism that promise benefits based on consideration of image, authenticity, personality and lifestyle of art and culture

\footnotetext{
1 Research Organization of OIC Ritsumeikan University, Japan

${ }^{2,3}$ Department Architecture Faculty of Engineering Diponegoro Universit, Indonesia
} 
(Naisbitt and Aburdene in Daliman, 2012). The Authors highlighted the potential of craftsmen's settlement as part of the survivability concept in urbanism.

Kotagede is an old city located in southern Yogyakarta which is administratively located on the border of Yogyakarta and Bantul Regency. According to (Daliman, 2012), among the handicraft industries of the people of Yogyakarta, which gives identity to this city is the silver craft industry. At present, the area of silver industry mainly occupies the area of Prenggan and Purbayan Village (Kotagede District, Yogyakarta City) and Jagalan Village (Banguntapan, Bantul Regency). This shows that the potential existence of a silver craftsman settlement area is in the fringe area of Yogyakarta.

Kotagede's planning as a conservation area tends to place the area as a potential tourist attraction. One tourist attraction that is characteristic of Kotagede except Mataram Mosque is the silver industry centre which can be found in art shops and also in the local community in settlements area. As part of Yogyakarta City, Kotagede District has developed in harmony with the demands imposed on the Yogyakarta City on a macro basis as a protected area. Related with regulation, Primary service centres in Region IV Kotagede, covering trade and service functions related to tourism in the Kotagede region (RDTR, 2011), The small industrial zone or home industry (I) is defined as covering an area of approximately 271.5 hectares. Article 19 point g: Sub BWP Kotagede in Prenggan Village and Purbayan Village (RDTR, 2013). This regulation is the basis for selecting locations of research in Kotagede district.

Kotagede silver art appeared at the same time as the Islamic Mataram Kingdom in the $16^{\text {th }}$ Century. During the reign of Panembahan Senopati, Abdi Dalem Kriya were ordered to make jewellery from gold and silver. Then during the reign of Sultan Hamengku Buwono VIII, He was fascinated by the beauty of metal craft then ordered the craftsmen to continue and develop the art of metal crafts (www.indonesiakaya.com). Abdi dalem kriya (Javanese) lives in groups in a village which get a name according to the type of handicraft they do which can be still be found today around Kotagede (https://etnis.id). The Village's name for the Abdi Dalem Kriya, for example, the Village for gold and silver craftsmanship it has called Kemasan, for craftsmen of iron tools called Pandean. For Keris's Craftmenship its called Mranggi or Mraggen or now it is called Prenggan, and Bathikan for Batik Craftsmen (Daliman, 2000). The activities of the craftsmen in producing these handicrafts arts are proposed as the independent variable of production activity (X1) and storage activity (X2).

According to (Tarigan, 2007) Total production of craftsmanship is decreased after an earthquake caused by decreasing order from silver seller from Yogyakarta and outside. Apart from production activities that have generally not been running, because the damage suffered cannot be repaired in its entirety. So that the earthquake that occurred in Bantul 27 Mei 2006 have an impact on decreasing the number of foreign and domestic tourists visiting. Since 2006 there have been many changes related to buying-selling activities (X3) which are becoming more common on the main road (Mondorakan-Kemasan street).

The characteristics of the Kotagede area have changed due to changes in function as a result of economic growth and changes in building ownership which also tends to be economically oriented. Indications can be seen with the appearance of new buildings that replace old buildings (Yetti, 2018). There have been many studies before that discuss buildings in terms of culture and heritage in Kotagede. This study will present a different point of view in seeing settlement area and focus only on craftsmen activities as homebased workers. For home-based workers, whose home is also their workplace, housing is an essential productive asset. Home-based workers produce goods or services for the market from within or around their own homes. In countries, both rich and poor, they produce a wide range of low- and high-end goods and services for both domestic and 
global markets (Chen \& Sinha, 2016). In this study, it will refer to the production of the silver industry occurred in protected settlement areas.

One type of handicraft occupied by the majority of the Kotagede community is silver crafts. However, the raw materials for these crafts are not produced from the local area but must be imported from Cikotok, Wes Java (Amini, 2006). This argument reinforces that the reaching activity (accessibility) to the craftsmen's settlement is not only based on tourism needs but also the need for drops-in and out of raw materials imported from outside Kotagede location. Related with accessibility \& reaching activity, the beauty of the Javanese traditional building style in Kotagede goes in harmony with its distinctive streets. The uniqueness of Kotagede can be seen in its kampungs (villages) with their historic traditional buildings and narrow alleys, as well as 'jalan rukunan' which is small streets formed by a row of the yards of the houses (UNESCO, 2008). Rukun (Javanese) means along in harmony. Most of the small streets in Kotagede are narrow alleys less than three meters wide with four-meter high walled structures on both sides, all leading to the Pasar Gede market area. These capillary streets have a strong influence in shaping the character of the district. This potential can be raised as part of the accessibility variable (X4) so that tourism gets the sense of place from the narrow alley called Jalan Rukunan.

The existence of silver industry activities in the historical area making the settlements function near Kemasan, and Mondorakan street in Kotagede grow into an immediate business area and bring up the supporting function of industrial activity in its settlement area starting from production, storage, buying-selling activity and accessibility. The meanings of production in terms of economic aspects is intended as an activity that aims to increase the use-value of an item, both through increasing the form and use of time (Budhi, 2009). From the above understanding, production activities require production space if the activities are carried out at home as a characteristic of the home industry.

The objectivity of this research is to find out whether there is an effect of the silver home-based industry activity on settlement's change. This step is carried out by conducting verification research using theories related to home-based activity theory and settlement change. The novelty of this research is to see not only about Kotagede as historical area but also about the existence of Abdi Dalem Kriya generation in utilizing settlement space. The novelty proposed as an effort to provide recommendations for government and local people in Kotagede that support the survivability of the "Living Museum" program that was initiated. These integrated ideas can increase the income of craftsman through the perspective of the Author as an architect in seeing the potential of settlement space. If there is a significant effect of the home-based industry in settlement space, it is expected that the balance between future settlements in historic areas can survive together without losing its history. So that the survivability of the future traditional settlement is formed become a new concept in Yogyakarta as the city of culture, especially in Kotagede itself.

\section{METHODS}

The method used is a quantitative method using SPSS V26 software for windows. Multiple linear regression is a statistical analysis that will be used to find out how far the effect happened and what activities have the most influence. Simple linear regression models study the relationship between a single continuous dependent variable $\mathrm{Y}$ and one independent variable $\mathrm{X}$ If there are $\mathrm{k}>1$ independent variables, it is called multiple linear regression (Bangdiwala, 2018). 


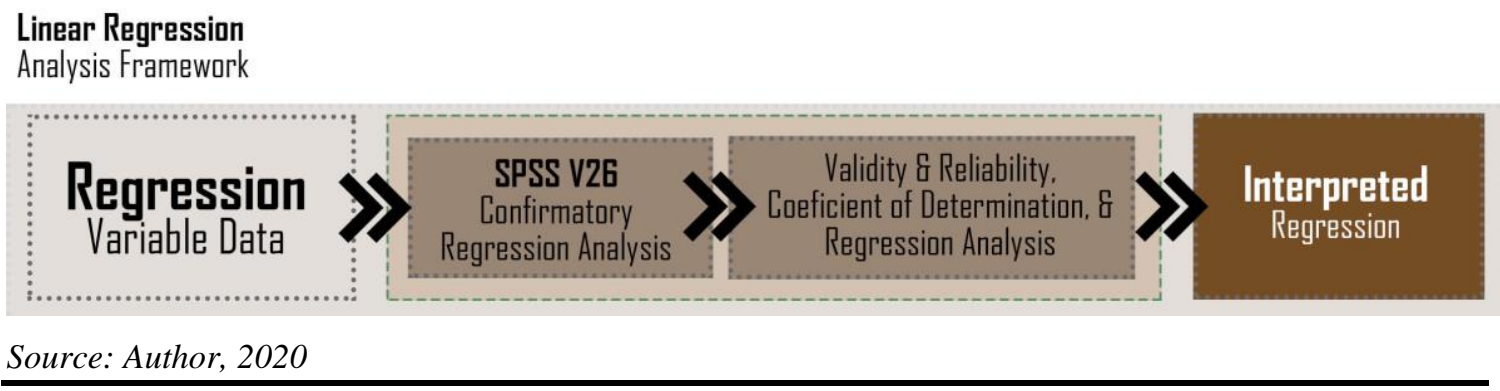

Figure 1. Research Staging scheme

Multiple linear regression analysis is an analytical technique used to determine whether there is an effect of independent variables in this research: Production activity (X1), Storage activity (X2) Buying-selling activity (X3) Reach activity to craftsman house or accessibility (X4) on the dependent variable: changes in the settlement space $(\mathrm{Y})$. The general formula of the multiple linear regression equation according to (Wirawan, 2002) as follows:

$$
\mathrm{Y}=\alpha+\beta 1 \mathrm{X} 1+\beta 2 \mathrm{X} 2+\beta 3 \mathrm{X} 3+\beta 4 \mathrm{X} 4+\mu
$$

$\mathrm{Y}=$ change in the Settlement area

$\mathrm{X} 1=$ Production Activity

$\mathrm{X} 2=$ Storage Activity

X3 = Buying-Selling Activity

$\mathrm{X} 4=$ Reach activity (accessibility) to a craftsman house

$\alpha=$ Intercept (constant) which describes the average effect of other variables that affect $Y$

but are not included in the regression equation

$\beta 1, \beta 2, \beta 3, \beta 4=$ The regression coefficient of each independent variable $\mathrm{X} 1, \mathrm{X} 2, \mathrm{X} 3, \mathrm{X} 4$

$\mu=$ Stochastic error (disturbance)

The positivistic paradigm was chosen in this study to verify the research subjects. Positivism is aligned with the hypothetico-deductive model of science that builds on verifying a priori hypotheses and experimentation by operationalizing variables and measures; results from hypothesis testing are used to inform and advance science (Park et al., 2020). From the method described, spatial and visual interpretation will make it easier to see what phenomenon that occurred and to analyze changes in the settlement area.

\section{DISCUSSION}

\section{Respondents Explanation}

A sampling of the respondent population was carried out by using probability sampling methods. Based on the sampling calculation that has carried out, the respondents in this study were 100 respondents who were evenly divided, consisting of 50 respondents from Purbayan Village and 50 respondent Prenggan Village. Characteristics of respondents can be explained through the diagrams below (See figure 2)

According to the age ratio of respondents divided into range 1 (15-35 Y.O) as $51 \%$; range 2 (36-55 Y.O) as $23 \%$ and range 3 (56-70 Y.O) as 26\%. Also, according to the occupation divided into civil servants as $15 \%$, student as $20 \%$, silver craftsmen at $30 \%$, and the private sector as $35 \%$. Whereas according to the gender ratio respondents consisted of $53 \%$ male respondents and $47 \%$ female respondents. 


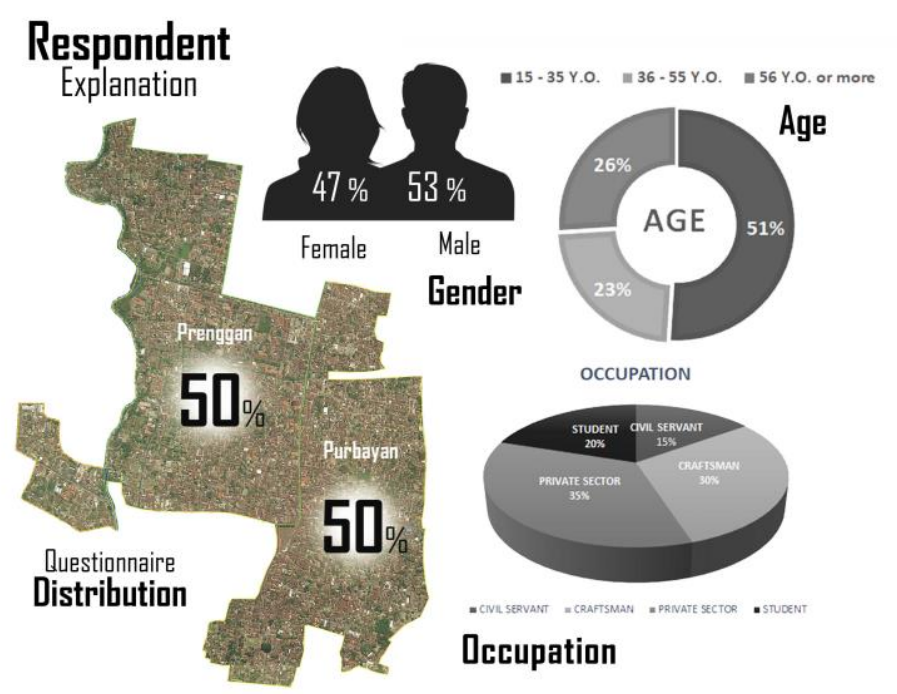

Source: Author, 2020

Figure 2. Respondents Explanation

\section{Statistical analysis}

The statistical analysis begins with the reliability test of the independent variable $(\mathrm{X})$, which consists of 8 indicator variables and the dependent $(\mathrm{Y})$, which consists of 6 variable indicators after removing some variables that do not match with the criteria.

Table 1. SPPS output results: reliability statistic variable Silver Industry Activity (X)

Reliability Statistics

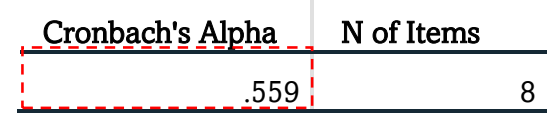

Source: Author, 2020

From the results of the reliability test (Table 1 and Table 2), it shows that the independent variable (X) has a Cronbach's Alpha value of 0.559 and dependent variable (Y) has Cronbach's Alpha value of 0.593, which means both of independent variable and dependent variable in the range of interval $0.400-0.600$ which can be said to be quite reliable (Sudijono, 2005).

Table 2. SPPS output results: reliability statistic variable Changes in Settlement area (Y) Reliability Statistics

$\frac{\text { Cronbach's Alpha } \quad \text { of Items }}{}$

Source: Author, 2020

After the reliability test and get the result of both variables used can be continued as a measurement tool for further analysis. The coefficient of determination and ANOVA test is carried out to determine how much influence the independent variable $(\mathrm{X})$ has on the dependent variable $(\mathrm{Y})$ either simultaneously or partially which can be seen in the following table (see table 3): 
Table 3. SPPS output results: Coefficient of Determination Model Summary

\begin{tabular}{|c|c|c|c|c|}
\hline \multicolumn{5}{|c|}{ Model Summary } \\
\hline Model & $\mathbf{R}$ & R Square & $\begin{array}{l}\text { Adjusted R } \\
\text { Square }\end{array}$ & $\begin{array}{l}\text { Std. Error of the } \\
\text { Estimate }\end{array}$ \\
\hline 1 & .50 & 256 & .224 & $.37 \varepsilon$ \\
\hline
\end{tabular}

a. Predictors: (Constant), X4, X2, X1, X3

b. Dependent Variable: $Y$

Source: Author, 2020

According to table 3 , the correlation value of $\mathrm{R}$ is 0.506 , which states a moderate relationship between silver industry activities and changes in the settlement area. While the value of $\mathrm{R}$ square shows the number 0.256 which in this case means that the respondent prefers to state that settlement area changes are affected by silver home-based industry activities by $25.6 \%$ while other factors outside the model impact the remaining of $74.4 \%$. After getting the results from the $\mathrm{R}$ square followed by the ANOVA test using a significance level of 0.05 with the following results (See table 4):

Table 4. SPPS output results: Anova Test

\begin{tabular}{|c|c|c|c|c|c|}
\hline \multicolumn{6}{|c|}{ ANOVA $^{a}$} \\
\hline Model & Sum of Squares & $\mathrm{df}$ & Mean Square & $F$ & Sig. \\
\hline 1 Regression & 4.656 & 4 & 1.164 & 8.153 & $.000^{\mathrm{b}}$ \\
\hline Residual & 13.563 & 95 & .143 & & \\
\hline Total & 18.218 & 99 & & & \\
\hline
\end{tabular}
a. Dependent Variable: Y
b. Predictors: (Constant), X4, X2, X1, X3

Source: Author, 2020

Statistical Test Result $(\mathrm{F})$ can be seen in the ANOVA table in the sig column. If the probability value $<0.05$, it can be concluded that there is a significant influence between variable $\mathrm{X}$ and variable $\mathrm{Y}$. Based on table $4, \mathrm{~F}$ test value is 8.153 with the probability of 0.000 . This value indicates that all variables that are entered into the model simultaneously affect changes in the settlement area. After testing the coefficient of determination, it is continued by looking at the normality of the data in the regression to ensure that the data is normally distributed so that it meets the assumptions of normality (see figure 3):
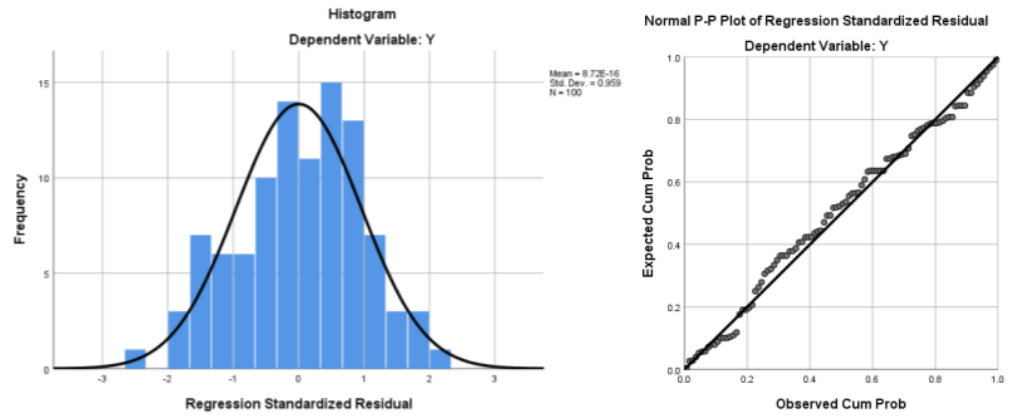

Source: Author, 2020

Figure 3. Normal Graph of Probability of Plots and Histograms 
Based on the appearance of a normal probability plot graph where the points spread around the diagonal line and follow the direction of the diagonal line and also the histogram forms a U-curve which can be interpreted that the regression model of the independent variable $(\mathrm{X})$ and dependent variable $(\mathrm{Y})$ meets the assumption of normality. Next, simultaneous testing is done to find out how much the significance of the variable (X) simultaneously affects the variable (Y). Based on figure 3 above, it can be said that the data is normally distributed because the data spread around the diagonal line and follows the direction of the diagonal line or the histogram graph. The subsequent analysis is the significance test $(\mathrm{T})$ to test for each variable partially. The results of T-test can be seen in the coefficients table in the column of significance. If the probability of the $\mathrm{T}$ value $<0.05$, it means that there is a significant influence between the independent variable and the dependent variable, which can be seen in the following table (Table 5):

Table 5. SPPS output results: T-test

Coefficients ${ }^{a}$

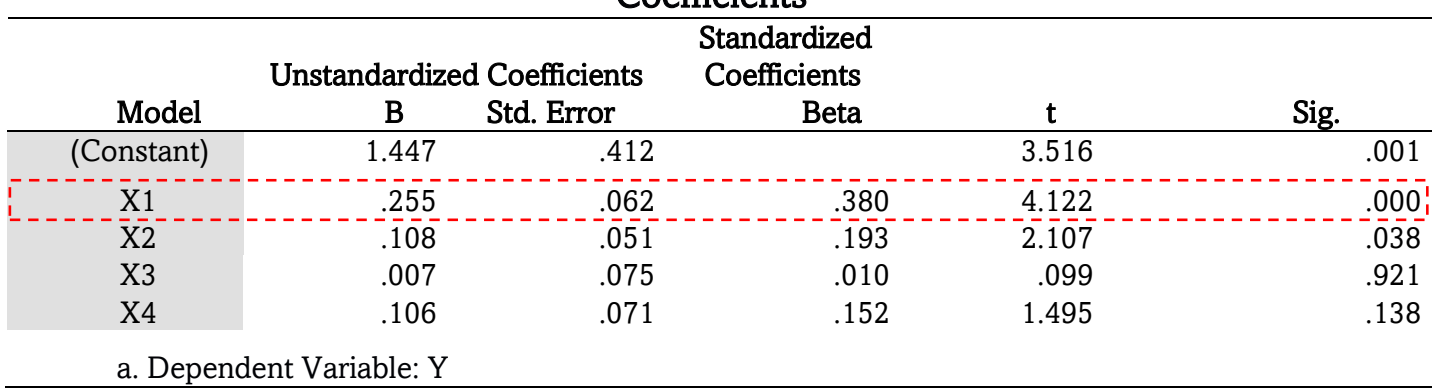

Source: Author, 2020

From table 5 above, it can be seen that the highest significance value $(0.000)$ is production activities (X1). From the overall statistical analysis above shows that there is a significant relationship between the two variables, which is $25.6 \%$, while other factors outside the model impact the remaining $74.4 \%$. After obtaining the statistical analysis results, it is continued to interpret the findings in a descriptive narrative with documentation and space requirements diagrams.

\section{Data Interpretation}

The definition of settlement according to Yunus (1987) in (Wesnawa, 2015) it can be interpreted as either a human-made or natural formation with all its support used by humans as individuals and groups to live temporarily or permanently in order to carry out their lives. Also, the real difference between settlement and housing in their function. In settlement areas, the environment has a dual function, as a place to live and at the same time, a place to make a living for some of the resident (Sadana, 2014). Furthermore in Law No.1 of 2011 concerning Housing and Settlement Areas has also emphasized that: "Settlements are part of the residential environment consisting of more than one housing unit which has infrastructure, facilities, public utilities, and has supporting function activities for other functions in urban or rural areas" (Law Number 1 Year 2011 regarding Housing and Settlement Areas). Based on the above understanding, the craftsmen activity as home workers can be seen as supporting regular household activities which at the same time can also support tourism activities in urban areas. These various kinds of activity will ultimately have an impact on changes in settlement area according to the level of its complexity.

In additional, Ekistics Theory is a tool that is considered appropriate for understanding the settlement. Classification scheme related to elements of settlements, 
namely nature, Anthropos, society, shells, and networks (Farizkha et al., 2019). Whereas space, especially in the context of a settlement, is a product of social activities (Lefebre, 1991). Socio-cultural changes without the support of superior planning which considering the aspects of internal, social and economic growth leading to greater resilience of culture and prosperity in the area of cultural heritage (Suryanti et al., 2014). From the whole theory related to changes in settlement space, in this study, the dependent variable will be selected related with changes in settlement area (Y) which will then be analyzed statistically and interpreted descriptively with several house samples that represent the intended activity and change itself.

An area is a place where all a variety of activities are carried out. The emergence of an area is not immediately formed, but it requires a process that has a certain period, and there are historical factors behind. The results conducted a combination of culture, social, and economic activities of the community who live in it, to create space in the house and settlement area that adapts to the needs of its inhabitants. (see figure 4):

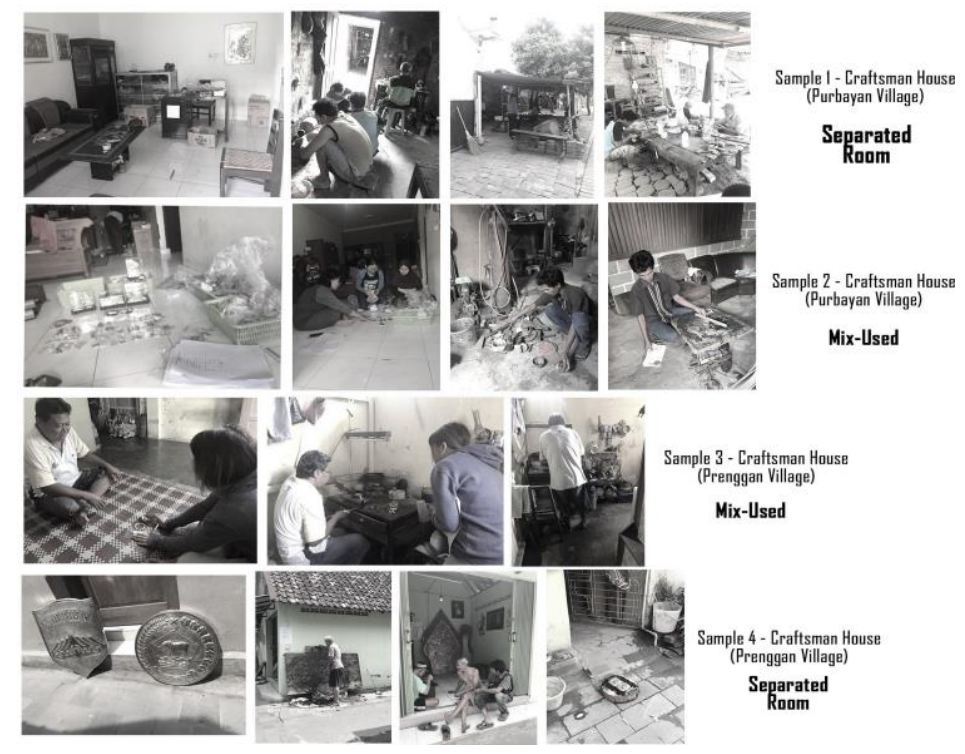

Source: Author, 2020

Figure 4. Silver industry activity that utilizes settlement area

Production activities (X1) that were found both traditional and modern (using machines) were found in almost all settlement area. Some craftsmen have used modern techniques such as using moulds to support their production techniques for the bracing process and forming a particular specific pattern. This affects the need for production space according to the complexity of its process. Regarding the various types of space needs in the function of craftsmen's settlement, it can be explained in the following figure (see figure 5):

In the sample of craftsmen houses above, it can be found differences in the use of settlement space between Purbayan and Prenggan villages. In the sample of houses in Purbayan village (sample 1 and sample 2), the craftsmen still have yards that are used as drying space and expanded as production space (outdoor). The red colour in the sample of house plans indicates the space most often used in production activity (X1). Even in sample 1, production activity (X1), storage activity (X2), and buying-selling activities (X3) occurs in the living room inside the houses. The facts found in the Purbayan Village are 
the road network is more comfortable to reach by visitors, and there are still so many house-yards to facilitate parking lot space so that the accessibility (X4) is easier to do.

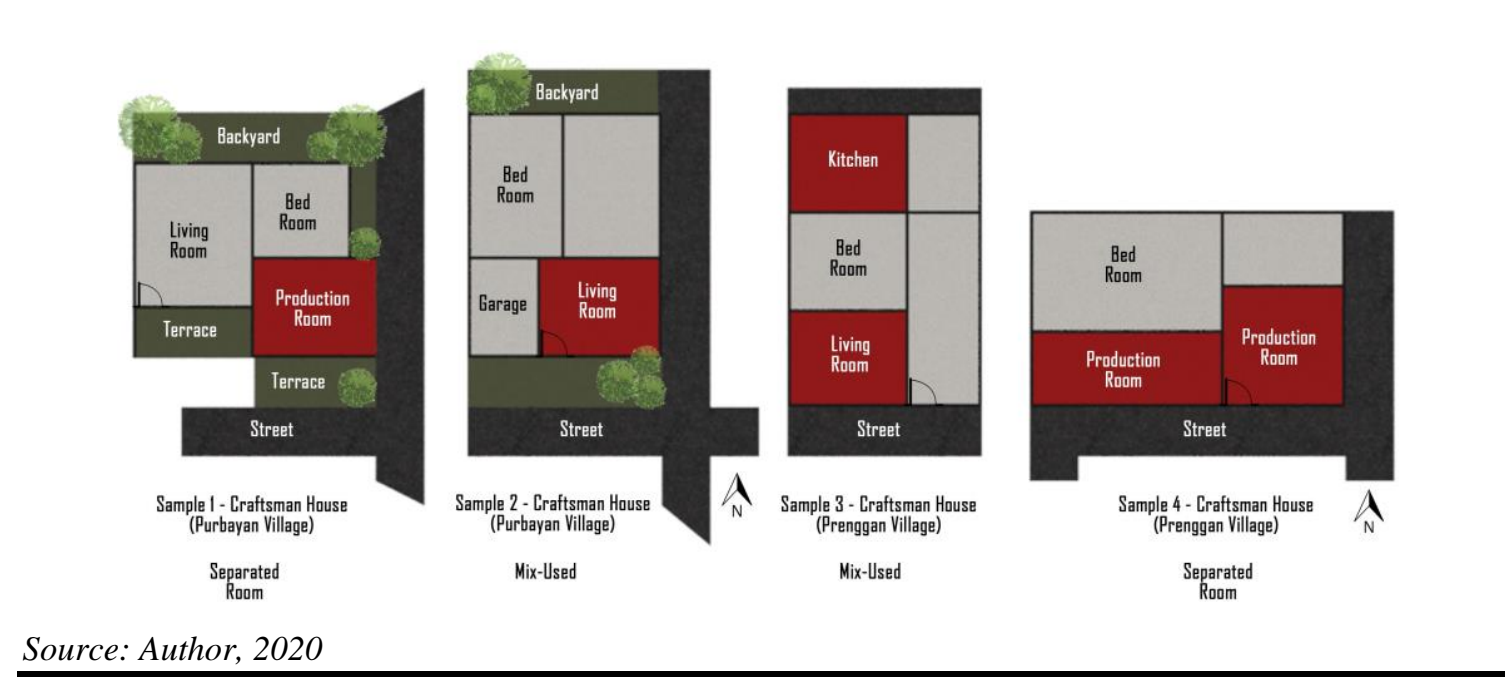

Figure 5. Craftsmen houses sample 1-4

This is a different finding from the sample of craftsmen's houses in Prenggan village, where they do not have yards and use the space simultaneously with household activities (mix-used). For example, in sample 3, the kitchen and living room are mix-used with regular household activities, and they sell their products to the large-scale silver industry near the main road or art shops. Based on the interview, they do not have enough space for storage activity (X2) and buying-selling activities (X3). However, there are also samples of houses that have separated production space from their house and its part of the expansion of the space that was previously as home-yard.

The changing dimensions of human settlements and the change in their character from static to dynamic, which gives them different aspects with every day that passes, makes the confusing settlements places in which to live, and people, instead of facing this new problem with realism, start trying to escape from the confusion (Doxiadis, 1970). The original culture of the house as a function of shelter for protection and as an image of social and cultural values has developed and turned into productive economic activities (Tarigan, 2015).

The purpose of this study is to be able to see the extent of the influence of homebased industry activities on settlement area changes. It is hoped that culture-based industries can survive mostly in the pandemic situation, which is quite detrimental for small-scale business but still should be considering the survivability of traditional settlements. The results of the partial analysis of the independent variable show that all variables (X1, X2, X3, X4) affect the change in settlement changes $(\mathrm{Y})$ and the highest variable effect on settlement changes in production activities (X1) that can be found in Purbayan and Prenggan Village. Production activity divided into machine orientation and manual, which both of them can be found in almost all samples of production activities that occur in craftsmen's settlements. Storage activity (X2) following the second-highest after production activity; in this case, temporary storage utilizes space in the house without impacting road space, or house-yard (private-public space). Buying and selling activities (X3) and accessibility (X4) were found mostly in the large-scale industry and art shops near Kemasan and Mondorakan street due to public reach and ease of parking lot areas. 
Change is a process that results in different conditions now from before, can be in the form of progress or decline, is a process of development from time to time that can make a difference in terms of structure and function (Darmadi \& Mutiari, 2015). If the changes are related to the site (Bukit et al., 2012), then the changes can be in the form of addition of elements, elimination of elements, and movements that cause changes in position. If we can develop a science of human settlements and, through it, recognize the guiding principles, laws, and procedures of man's action regarding terrestrial space, we can build much better human settlements in the future (Doxiadis, 1970).

From the discussion above, the researcher finds that with the low significant impact results on settlement changes, It is hoped that the silver home-based industry has the potential to be promoted as part of the survivability concept of tourism in Kotagede by advancing SMEs itself. By integrating buying-selling activities (X3) and accessibility (X4), tourism as visitors can reach the craftsmen's settlement easier with the mapping guide. The recommendation given is to create a master plan for mapping distribution of craftsmen's houses that are still existing by analyzing potential points of visitor parking and clarity of entry and exit routes. The purpose of the distribution mapping is so that visitors can easily reach the craftsmen's house and not only focus on large-scale industries and art shops along the main road.

The master plan design concept must also consider and adapt to the conditions of cultural heritage area and the space requirements for the silver craftsman in the future. This aims to anticipate future impacts related to the changes in residential space to commercial space focuses on heritage settlement area. The government can cooperate with Architects and cultural researchers to integrate the three aspects of the findings in this study, which is the existence of silver craftsmen generation (Javanese: Abdi dalem kriya), potential space for tourism activities, and SMEs without forgetting the image of Kotagede as a heritage area. Efforts can be made by holding a design competition for architects or group discussion forum involving citizen participation in determining policy directions for a spatial planning that can provide benefits for all parties.

\section{CONCLUSION}

Tourism activities in Yogyakarta have a multiplier effect on the development of other sectors, particularly the industrial, trade, labour and education sectors, which in turn can encourage job opportunities (Armiyati, 2014). A strategy for cultural resources conservation was proposed to face the process of changes in the cultural sector in the planning documents (Suryanti et al., 2014). Before the earthquake that occurred in 2006, there was a program namely "Living Museum" in Kotagede. Tourist has often taken on a tour of the settlement areas of the community who work as craftsmen so that their attention is not only focused on large-scale silver industry or art shops near the main road (Sujanto, 2015). According to (Adhelia et al., 2015) the establishment of the "Jogja Heritage City" program as an effort of the provincial government in realizing the tourism vision of Yogyakarta has received a positive response from local governments and business actors. However, it is contrary to the wishes of the local people (community) who do not want Kotagede to become mass tourism. Also, From a review of tourism planning programs that have been implemented in Kotagede before, the Author formulates thoughts on how craftsmen can survive in each change.

Silver Industry in Kotagede is not just an attempt to gain profit; it contains the history of the Javanese people local wisdom (Armiyati, 2014). The raises problems such as the phenomenon of settlement area which was initially organic before and changed according to the needs of supporting the silver industry activities as a source of the local community's economy, which in turn is feared that it will lose its inherent identity. The 
main problems of the silver industry during the crisis in 1997, revolved around production and marketing activities (Armiyati, 2014). Some craftsmen prefer to sell their products to a large-scale industry near the main road, but there is some craftsman who still survives to sell independently. According to (Adhelia et al., 2015) when viewed from the stakeholder cooperation that occurred in the development of tourist areas, Kotagede showed a low value. Thus, although the components of tourism development Kotagede shows the alignment of sustainability, the resulting relationship is still weak.

Practices of survivability can be scaled up, down, and in between, enabling the building of further possibilities in the fight against gentrification (Lees, Annunziata, \& RivasAlonso, 2018). Based on the findings in the field, it is shown that the activity of the silver home-based industry (X1) towards changes in the settlement area (Y) shows a low significance change, where settlement function still retains the characteristics of traditional settlements in protected areas even though various kinds of small-scale industrial activities are increasing in this area. After the analysis was obtained, it was also found that there was an effect of Silver home-based Industry Activities on Change in residential space function with the low significance of $25.6 \%$ while $74.4 \%$ was thought to be influenced by other activities outside the research model. As a result of settlement function changes, observers can perceive cognitively, and visually the activities that make up these changes lead to positive changes and remain under the regulations that have been imposed in Kotagede as a protected area.

\section{ACKNOWLEDGEMENT}

Thanks to all those who helped fill out the questionnaire in this study and also the silver craftsmen as residents who were willing to become a key person in face to face questionnaire session. Highly appreciation also to the local community in Purbayan and Prenggan Villages.

\section{REFERENCES}

Adhelia, N., Soedwiwahjono, S., \& Yudana, G. (2015). Keterpaduan Komponen Pengembangan Pariwisata Kotagede Sebagai Kawasan Wisata Budaya Berkelanjutan. Region: Jurnal Pembangunan Wilayah Dan Perencanaan Partisipatif, 6(1), 14. https://doi.org/10.20961/region.v6i1.8496

Amini, M. (2006). Aktivitas Ekonomi Orang Kalang di Kotagede Pada Masa Depresi 1930T. 18(2), 157-164.

Anonymus. (2011). Detailed Spatial Plan of Yogyakarta. Yogyakarta: Rencana Detail Tata Ruang (RDTR).

Anonymus. (2013). Detailed Spatial Plan of Yogyakarta. Rencana Detail Tata Ruang (RDTR).

Arifini, K., \& Mustika, M. (2013). Analisis Pendapatan Pengrajin Perak Di Desa Kamasan Kabupaten Klungkung. E-Jurnal Ekonomi Pembangunan Universitas Udayana, 2(6), 294-305.

Armiyati, L. (2014). Industri Perak Kotagede Yogyakarta Melawan Badai Krisis. Jurnal Sejarah Dan Budaya, 2(1), 1-11.

Bangdiwala, S. I. (2018). Regression: multiple linear. International Journal of Injury Control and Safety Promotion, 25(2), 232-236. https://doi.org/10.1080/17457300.2018.1452336

Budhi, M. K. (2009). Teori Ekonomi Mikro. Denpasar: Udayana University Press.

Bukit, E. S., Hanan, H., \& Wibowo, A. S. (2012). Aplikasi Metode N . J . Habraken pada Studi Transformasi. Jurnal Lingkungan Binaan Indonesia $V, 1(1), 51-62$.

Chen, M. A., \& Sinha, S. (2016). Home-based workers and cities. Environment and Urbanization, 28(2), 343358. https://doi.org/10.1177/0956247816649865

Daliman, A. (2012). Peranan Industri Seni Kerajinan Perak Di Daerah Istimewa Yogyakarta Sebagai Pendukung Pariwisata Budaya. Humaniora, 12(2), 170-180. https://doi.org/10.22146/jh.v12i2.687

Darmadi, D., \& Mutiari, D. (2015). Perubahan Fungsi Ruang Rumah Kuno Di Kampung Kauman Surakarta. Sinektika: Jurnal Arsitektur, 13(2), 76-82. https://doi.org/10.23917/sinektika.v13i2.750

Doxiadis, C. A. (1970). Ekistics, the science of human settlements. Science, 170(3956), 393-404. https://doi.org/10.1126/science.170.3956.393 
Farizkha, I. A., Koesoemawati, R. R. D. J., Suprobo, R. A., Listyawati, R. N., \& Hayati, N. N. (2019). Urban settlement growth factors through ekistics element approach (Case study: Jember City). IOP Conference Series: Earth and Environmental Science, 340(1). https://doi.org/10.1088/17551315/340/1/012024

Lees, L., Annunziata, S., \& Rivas-Alonso, C. (2018). Resisting Planetary Gentrification: The Value of Survivability in the Fight to Stay Put. Annals of the American Association of Geographers, 108(2), 346355. https://doi.org/10.1080/24694452.2017.1365587

Park, Y. S., Konge, L., \& Artino, A. R. (2020). The Positivism Paradigm of Research. Academic Medicine, 95(5), 690-694. https://doi.org/10.1097/ACM.0000000000003093

Sadana, S. A. (2014). Perencanaan Kawasan Permukiman. Jakarta.

Sudijono, A. (2005). Pengantar Statistik Pendidikan. PT. Raja Grafindo Persada.

Sujanto, R. Y. (2015). Manajemen Komunikasi Badan Lingkungan Hidup Kota Yogyakarta dalam Penanganan Limbah Perak di Kotagede. CHANNEL Jurnal Komunikasi, 3(1), $46-54$. https://doi.org/10.12928/channel.v3i1.2413

Suryanti, E., Sumartono, S., \& Hermawan, H. (2014). Culture Development Planning in the Special Region of Yogyakarta (Management Planning of Cultural Heritage in Kotagede District based on Community Empowerment Conservation Model). Journal of Indonesian Tourism and Development Studies, 2(3), 120-128. https://doi.org/10.21776/ub.jitode.2014.002.03.05

Tarigan, R. (2015). Tantangan pelestarian dan perubahan terhadap manfaat ruang tradisional akibat pengaruh kegiatan industri rumah tangga. Jurnal Arsitektur Komposisi, 11 no.2, 77-84.

Tarigan, Y. P. (2007). The Earthquake Impact to Performance of Small Scale Silvert Crafting Industry in Kotagede, Yogyakarta. Yogyakarta: Universitas Atma Jaya Yogyakarta.

UNESCO. (2008). Homeowner's conservation manual: Kotagede heritage district, Yogyakarta, Indonesia (Pedoman pelestarian bagi pemilik rumah: Kawasan Pusaka Kotagede, Yogyakarta, Indonesia). Retrieved from https://unesdoc.unesco.org/ark:/48223/pf0000180608

Wesnawa, I. G. A. (2015). Geografi Permukiman. Yogyakarta: Graha Ilmu.

Wirawan, N. (2002). Statistik 2 (Statistik Inferensif) (2nd Editio). Denpasar: Keraras Emas.

Yetti, A. E. (2018). Preservasi Kawasan Perdagangan Kotagede Yogyakarta Dengan Pendekatan Adaptive Reuse. Jurnal Arsitektur Dan Perencanaan (JUARA), 1(1), 14-26. https://doi.org/10.31101/juara.v1i1.369 